\title{
latrogenic Postvaccinal Injection Site Granulomas in Cattle
}

\author{
Natália Picoli Folchini', Liliane Zanatta', Lays Wouters Ugolini', Tanise Policarpo Machado ${ }^{2}$, \\ Adriana Costa da Motta ${ }^{2}$, Ricardo Reis Bohrer ${ }^{3}$ \& Carlos Bondan ${ }^{1}$
}

\begin{abstract}
Background: The Brazilian government has established disease eradication and control programs to protect livestock from pathogens that affect animal health and compromise animal protein production and food safety and quality. Vaccination campaigns against foot-and-mouth disease and other infectious diseases in cattle except brucellosis can be carried out by non-veterinarian employees. However, vaccination errors can result in the formation of granulomas at injection sites that can affect animal welfare and production. The present study aimed to report two cases of granulomas at injection sites due to the inadvertent administration of vaccines containing saponins and mineral oil as adjuvants.

Cases: Case 1. The history was that a 2-year-old Devon steer was down for 7 days and was vaccinated 20 days ago with a vaccine containing saponins and mineral oil as adjuvants. Case 2. A 7-month-old Holstein heifer was examinated due to a 40-day history of ataxia, forelimb paresis progressing to tetraparesis, and vaccination with a vaccine containing saponins and mineral oil as adjuvants 60 days ago. These two animals were admitted in the Veterinary Hospital from the University of Passo Fundo (UPF) with a clinical history of incoordination and permanent decubitus after vaccination. The disease had a similar clinical course in both animals. Clinical signs included the presence of a palpable cervical mass at the site of vaccination, forelimb paresis that progressed to tetraparesis, and decubitus scars. Treatment included intravenous administration of anti-inflammatory steroids, antibiotic therapy, daily cleansing of the pressure sores, all four limbs were massaged, animals underwent several physiotherapy sessions, slings were used to mantain recumbent patients in a standing position and supportive therapy consisted of fluid therapy and oral supplementation. Animals remained hospitalized for approximately 40 days. Pacients experienced temporary improvement during treatment, and would walk with an uncoordinated gait. The clinical picture worsened after treatment was discontinued, necessitating euthanasia. At necropsy, gross lesions were similar in both animals. In case 1, the trapezius was firm and pale and had multiple granulomas which extended into the cervical vertebral column at $\mathrm{C} 3-\mathrm{C} 4$ and invaded the spinal canal compressing the spinal cord. In case 2, there was extensive damage to the trapezius by granulomatous inflammation; numerous nodular granulomas exuded milky contents. These lesions extended deep into the muscle fibers and infiltrated the vertebral column at C5-C6, with involvement of the medullary canal and spinal cord compression. Microscopically there was severe, diffuse pyogranulomatous myositis. Each pyogranuloma had a central clear space. Nodal architecture was effaced by these inflammatory nodules.

Discussion: Some drugs and vaccines contain irritating adjuvants and induce granuloma formation at the inoculation site. In both cattle, vaccines were injected intramuscularly in the cranial third of the neck in close proximity to the cervical vertebrae and surrounding tissues. These vaccines possibly induced an exuberant inflammatory reaction at the inoculation site. An exacerbated inflammatory response following the administration of adjuvanted vaccines by improperly trained personnel caused substantial tissue damage at the injection site. Severe, locally extensive lesions were found at necropsy affecting adjacent structures including skeletal muscles and spinal cord. The clinical signs of ataxia and forelimb paresis that progressed to tetraparesis were due to the marked pyogranulomatous inflammation in $\mathrm{C} 3-\mathrm{C} 4$ in case 1 and in $\mathrm{C} 5-\mathrm{C} 6$ in case 2. The present study reinforces the importance of good farming practices and properly trained personnel working at farms.
\end{abstract}

Keywords: bovine, vaccine, infection site, granuloma, iatrogenic. 


\section{INTRODUCTION}

In 2016, Brazil had 219,180,000 bovines and slaughtered $38,365,000$ heads $[3,19]$. In the same year, Brazil exported 1,351,027 tonnes of beef [2]. These figures show the country's potential in terms of global food production.

The Brazilian government has established disease eradication and control programs to protect livestock from pathogens that affect animal health and compromise animal protein production and food safety and quality. The goal of the PNEFA (National Program for Prevention and Eradication of Foot-and-Mouth Disease) and PNCEBT (National Program for the Control and Eradication of Brucellosis and Tuberculosis) is to eliminate these diseases from Brazilian cattle herds [12,14]. Surveillance programmes for brucellosis and tuberculosis include periodic testing for these diseases which are carried out by accredited veterinarians from the Ministry of Agriculture, Livestock and Supply (MAPA).

Systematic mass vaccination campaigns against foot-and-mouth disease and other infectious diseases in cattle except brucellosis can be carried out by non-veterinarian employees. However, inadequately or insufficiently trained personnel working at these farms can make mistakes during this procedure, and granuloma formation at the site of injection can occur due to vaccination errors. Iatrogenic postvaccinal injection site granulomas can affect animal welfare and production. They cause discomfort, production losses, reduction in live weight and carcass yield and ban on imports of fresh meat $[1,5,10,11]$.

The present study aimed to report two cases of granulomas at injection sites due to the inadvertent administration of vaccines containing saponins and mineral oil as adjuvants.

\section{CASES}

Two cattle from different farms with a clinical history of gait abnormalities and prolonged or permanent decubitus after vaccination were referred on different occasions to the Large Animal Clinics of the Veterinary Hospital from the University of Passo Fundo (UPF).

Case 1. The history was that the animal (a 2-year-old Devon steer ) was down for 7 days and was vaccinated 20 days ago with a vaccine containing saponins and mineral oil as adjuvants.
Case 2. A 7-month-old Holstein heifer with a 40-day history of ataxia, forelimb paresis progressing to tetraparesis, and vaccination with a vaccine containing saponins and mineral oil as adjuvants 60 days ago. The disease had a similar clinical course in both animals. Clinical signs included the presence of a wellcircumscribed cervical mass at the site of vaccination, forelimb paresis that progressed to tetraparesis, and pressure sores.

Treatment included intravenous administration of anti-inflammatory steroids (Disodium phosphate dexamethasone $\left.{ }^{\circledR}\right)^{1}$ from day 1 to day 4, $20 \mathrm{mg}$ total; on day 6 and on day 8, $20 \mathrm{mg}$ total; on day 10 and on day $12,10 \mathrm{mg}$ total; and on day 14 and day $16,5 \mathrm{mg}$ total; antibiotic therapy [Ampicillin sodium ${ }^{\circledR 1}, 10 \mathrm{mg} / \mathrm{kg} \mathrm{IV}$ s.i.d. for 7 days and gentamicin sulfate, $\left(\text { Gentatec }^{\circledR}\right)^{2}$, $4 \mathrm{mg} / \mathrm{kg}$ IV s.i.d. for 7 days]; daily cleansing of the pressure sores and application of allantoin and zinc oxide ointments (Alantol ${ }^{\circledR 3}$, q.i.d.) to the affected areas; all four limbs were massaged with topical anti-inflammatory gel containing prednisolone acetate, lidocaine hydrochloride and dimethylsulfoxide (Ekyflogyl ${ }^{\circledR 4}$, q.i.d.), animals underwent several physiotherapy sessions consisting of joint flexion and extension of all four limbs repeated a number of times; slings were used to mantain recumbent patients in a standing position (q.i.d.); supportive therapy consisted of fluid therapy and oral supplementation with amino acids, vitamins and yeasts $\left(\text { Organew }{ }^{\circledR}\right)^{3}$.

Animals remained hospitalized for approximately 40 days. Pacients experienced temporary improvement during treatment; they would walk with an uncoordinated gait. The clinical picture worsened after treatment was discontinued, necessitating euthanasia. Euthanasia was conducted with the consent of the owners and according to the guidelines on methods of euthanasia (resolution no. 1,000) issued on May 11, 2012 by the Federal Council of Veterinary Medicine (CFMV) of Brazil [6]. A local anesthetic (Cloridrato de Lidocaína $\left.{ }^{\circledR}\right)^{5}$ was intrathecally administered before general anesthesia. After euthanasia, carcasses were submitted for necropsy at the Department of Veterinary Pathology from the same university.

Gross lesions were similar in both animals. In case 1, the trapezius was firm and pale and had multiple granulomas which extended into the cervical vertebral column at $\mathrm{C} 3-\mathrm{C} 4$ (Figure 1) and invaded the spinal canal compressing the spinal cord. In case 2, there was extensive 
damage to the trapezius by granulomatous inflammation; numerous nodular granulomas were present which exuded a milky secretion (probably vaccine material) [figure 2A]. These lesions extended deep into the muscle fibers and infiltrated the vertebral column at C5-C6 with involvement of the medullary canal and spinal cord impingement (Figure 2B). The cervical and prescapular lymph nodes were enlarged, firm, and irregular on cut surface.

Microscopically there was severe, diffuse pyogranulomatous myositis characterized by the presence of numerous pyogranulomas separating or replacing necrotic skeletal myofibers. Each nodular inflammatory infiltrate had a central clear, empty space interpreted as vaccine adjuvant. Nodal architecture was effaced by these inflammatory nodules.

\section{DISCUSSION}

In the present study, the diagnosis of iatrogenic postvaccinal injection site granulomas was based on the history, clinical signs, gross lesions and microscopic findings.

In both cattle, vaccines were injected intramuscularly in the cranial third of the neck in close proximity to the cervical vertebrae and surrounding tissues. These vaccines possibly induced an exuberant inflammatory reaction at the inoculation site. A presumptive clinical diagnosis of iatrogenic postvaccinal granuloma was made based on the history of vaccination and the presence of a large cervical mass at the injection site, and was confirmed at necropsy and histologically.

In the present study, the gross findings were similar to those reported previously by other researchers $[1,10,12]$. In both of our cases there was some variation in the size and location of the granulomas and adjacent structures that were being compressed by these inflammatory lesions. Microscopically, there was pyogranulomatous myositis, and pyogranulomas had a central clear space as described in previous publications of cases of iatrogenic postvaccinal granuloma in cattle. These clear spaces surrounded by chronic-active, mixed cell inflammation are interpreted as vaccine adjuvant that was removed during histologic processing. Based on these histological findings, it has been suggested that tissue inflammation is induced by the vaccine adjuvant at the injection site $[15,18]$.

Some drugs and vaccines contain irritating adjuvants and induce granuloma formation at the inoculation site. Vaccine adjuvants potentiate and prolong

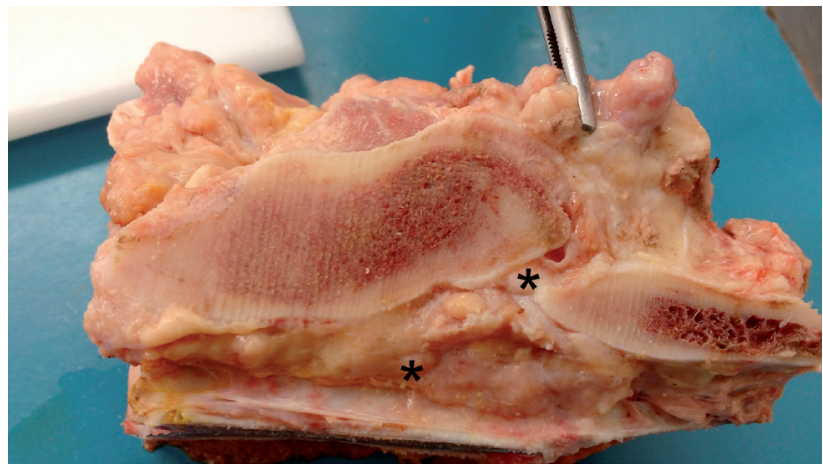

Figure 1. Bovine. Pyogranulomatous inflammation (forceps) spreads through the intervertebral foramen at $\mathrm{C} 3-\mathrm{C} 4$ into the spinal canal (asterisks).

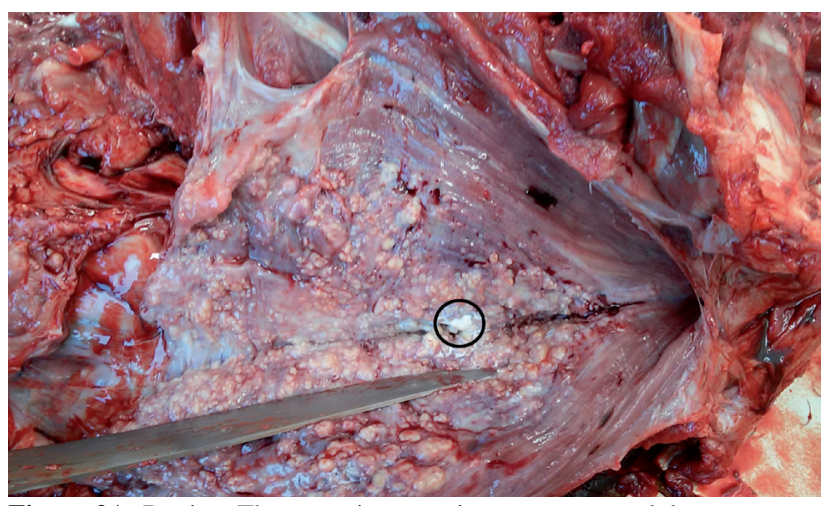

Figure 2A. Bovine. The trapezius contains numerous nodular pyogranulomas which exude milky contents interpreted as vaccine material (circle).

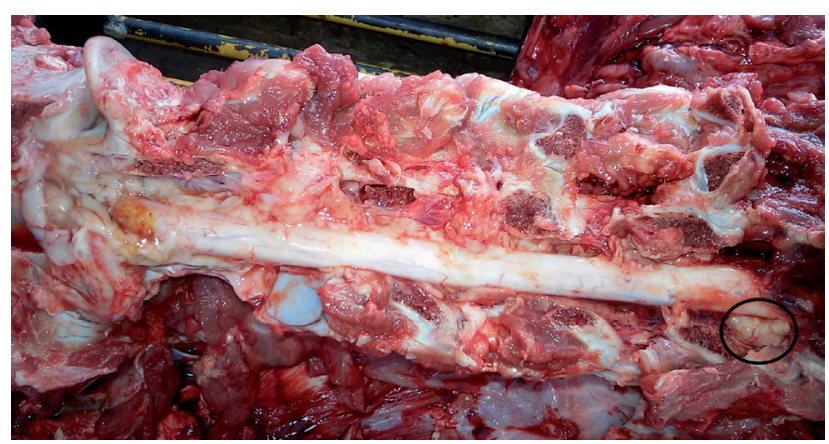

Figure 2B. Bovine. Pyogranulomatous inflammation affects the cervical vertebral column and spreads through the intervertebral foramen at C5-C6 into the spinal canal (circle).

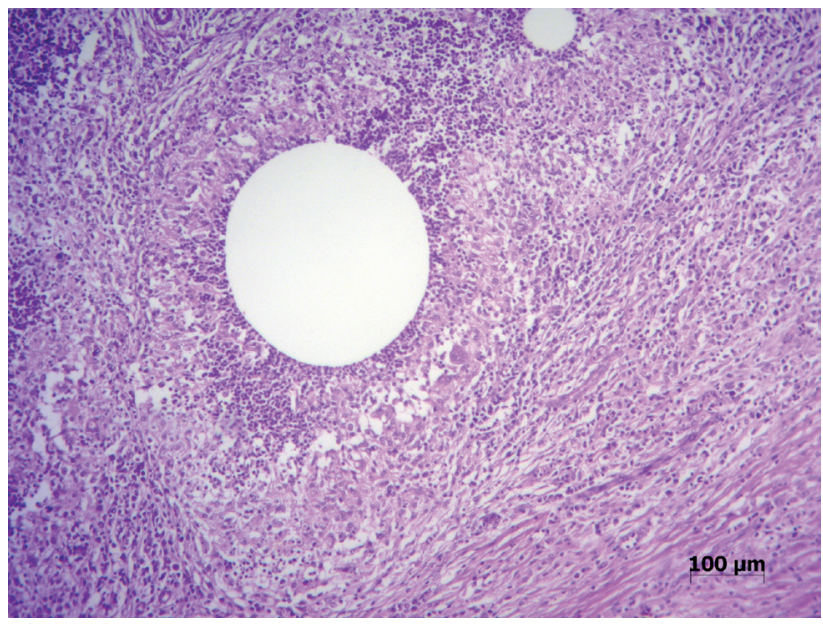

Figure 3. Bovine. Prescapular lymph node. Piogranulomatous lymphadenitis. This pyogranuloma consists of a central clear space (probably vaccine adjuvant) surrounded by neutrophils, mononuclear cells, and a fibrous capsule [HE, 100x] 
the immune response against an antigen as it is capable of modulating the innate immune system of the animal [17]. In our cases, the vaccines contained saponins and mineral oil as adjuvants which slowly release the encapsulated antigen inducing an inflammatory reaction and increasing the immune response to this antigen. An exacerbated inflammatory response following the administration of adjuvanted vaccines by improperly trained personnel caused substantial tissue damage at the injection site. Severe, locally extensive lesions were found at necropsy affecting adjacent structures including skeletal muscles and spinal cord.

Animals hospitalized at the local university veterinary hospital also had pressure sores from prolonged or permanent decubitus (decubitus ulcers). The clinical signs of ataxia and forelimb paresis that progressed to tetraparesis were due to the marked pyogranulomatous inflammation in $\mathrm{C} 3-\mathrm{C} 4$ in case 1 and in C5-C6 in case 2. Gait abnormalities vary according to the site of the spinal cord injury and degree of involvement of the spinal cord [4]. Lesions involving C1-C5 (cervical) and C6-T2 (cervicothoracic) spinal cord segments affect the movement of all four limbs. The severity of the neurological signs vary according to the degree of spinal cord compression. Hindlimb gait abnormalities occur when there is involvement of T3-L3 (thoracolumbar) or L4-S2 (lumbosacral) spinal cord segments. Cauda equina syndrome occurs if the lesion is located more caudally and affects the sacrococcygeal region of the spinal cord.

In a retrospective study published by Marques et al. [11], 24 cattle in Northeast Brazil developed gait abnormalities after vaccination against foot-and-mouth disease. Ubiali et al. [18] reported an outbreak of lumbar compressive myelopathy in Central Brazil in which 25 cattle were affected approximately 60 days after oily adjuvant vaccines against foot-and-mouth disease were improperly administered. Affected animals had firm nodules $5-8 \mathrm{~cm}$ in diameter in the longissimus lumborum, hindlimb paralysis, ataxia, a dog-sitting posture, urinary incontinence, decreased perianal reflex, flaccid tail, and mild rectal prolapse.

Iatrogenic postvaccinal injection site granulomas in cattle can affect production and cause significant economic losses, death of animals, and condemnation of parts of carcasses. Spinal cord compression due to iatrogenic postvaccinal granulomas affect animal welfare as they cause discomfort and pain to animals, and induce abnormalities in locomotion, prolonged recumbency, and pressure sores. Affected animals may present ataxia, inability to ambulate, incoordination, hypermetria, paresis, and paralysis [16]. Euthanasia is indicated in downer animals in permanent decubitus [11]. Sick animals may have difficulty to eat and move, requires special care and dedicated attention from staff, and develop a number of complications associated with prolonged recumbency such as pressure sores which negatively affect their well-being. Keeping these injured animals in the herd is not economically viable. Therefore, sick animals with a poor prognosis should be culled.

In cases in which injection site granulomas are found during meat inspection in slaughterhouses, veterinarians should follow the legislation and guidelines published by meat hygiene authorities in Brazil in order to choose the final destination of the carcasses. According to Article 134, item V, from the Regulation on Industrial and Sanitary Inspection Service of Products of Animal Origin [13], carcasses with localized abscesses should be withheld, and would be released for continued processing only after the affected parts are removed and condemned. In Federal and State meat processing plants from Brazil, trimming and removal and disposal of parts of the carcass unsuitable for human consumption during inspection decrease carcass yield.

Leal et al. [10] found 1,815 bovine carcasses slaughthered in a federal abattoir in Central Brazil that had injection site granulomas. These animals had been vaccinated with foot-and-mouth disease oily adjuvant vaccines. In these cases, an average of 1.8 to $2.0 \mathrm{~kg}$ of inedible muscle had to be removed during trimming, generating a total estimated loss of $\mathrm{R} \$ 20,412.90$ according to meat market prices at the time. In a bovine slaughterhouse under State inspection, Cardoso [5] found that $108.8 \mathrm{~kg}$ of tissues with abscesses had to be trimmed from 2,000 half carcasses (hemicarcasses) of beef resulting in a loss of $\mathrm{R} \$ 1.06$ per injury in each carcass. Assis et al. [1] reported that during the assessment of a total of 26,000 bovine hemicarcasses, $6,769(26 \%)$ had abscesses and 1,280 had hematomas. A total of $3,070.5 \mathrm{~kg}$ of inedible trim had to be removed generating an average loss of $0.220 \mathrm{~kg}$ per carcass and $\mathrm{R} \$ 15,887.45$ in direct losses caused by vaccination granulomas. In both of our cases, possibly the entire cervical region would have to be condemned during meat inspection due to the severity and extent of the pyogranulomatous inflammation. 
In Brazilian farms, vaccines and drugs are usually administered to cattle by non-veterinarian employees. Inadequately trained non-DVM staff can make mistakes during these procedures. Although these are relatively simple and straightforward techniques to perform, a few basic precautions and guidelines should be followed in order to prevent infection. Aseptic techniques that avoid microbial contamination include cleaning of the injection site with an antiseptic solution prior to medication administration, and the use of appropriate and clean needles, sterile syringes, and disinfected jet injectors [8]. In addition, it is important to find the correct site of drug or vaccine administration using the appropriate technique in order to prevent iatrogenic injuries.

In cattle, vaccines should be injected either subcutaneously or intramuscularly in the middle third of the neck [8]. This particular anatomical area is recommended as the ideal injection site in the bovine since it is formed by large muscle masses that provide protection to structures such as the nuchal ligament, cervical vertebrae, and cervical nerve roots [7,9]. Ad- ministration of a vaccine at the wrong site can damage important anatomical structures affecting the health of the individual. As a result, affected animals may experience pain and develop gait abnormalities if there is involvement of the spinal cord by inflammation.

The present study reinforces the importance of good farming practices and properly trained personnel working at farms. There should be periodic training updates to non-DVM staff involved in animal handling and restraint and engaged in prophylactic and control measures of infectious diseases in livestock including vaccination and drug administration.

\section{MANUFACTURERS}

${ }^{1}$ Laboratório Teuto Brasileiro S/A. Anápolis, GO, Brazil.

${ }^{2}$ Chemitec Agro-Veterinária Ltda. Jaboticabal, SP, Brazil

${ }^{3}$ Vetnil Ind. e Com. de Produtos Veterinários Ltda. Louveira, SP, Brazil.

${ }^{4}$ Hertape Calier Saúde Animal. Juatuba, MG, Brazil.

${ }^{5}$ Hipolabor Farmacêutica Ltda. Sabará, MG, Brazil.

Declaration of interest. The authors report no conflicts of interest. The authors alone are responsible for the content and writing of the paper.

\section{REFERENCES}

1 Assis D.R., Rezende-Lago N.C.M., Marchi P.G.F. \& Amato C.C.D. 2011. Perdas diretas ocasionadas por abscessos e hematomas em carcaças de bovinos. Revista Portuguesa de Ciências Veterinárias. 106(577-580): 47-51.

2 Associação Brasileira das Indústrias Exportadoras de Carnes. 2016. Exportação mundial de carne bovina: estatísticas: exportações: por ano. Disponível em < http://www.abiec.com.br/download/anual-2016.pdf>. [Accessed online in June 2017].

3 Associação Brasileira das Indústrias Exportadoras de Carnes. 2016. Exportação mundial de carne bovina: estatísticas: abates: 2016. Disponível em < http://sigsif.agricultura.gov.br/sigsif_cons/!ap_abate_estaduais_cons?p_select=SIM\&p_ ano=2016\&p_id_especie=9>. [Accessed online in July 2017].

4 Borges A.S. 2004. Sistema Nervoso. In: Feitosa F.L. (Ed). Semiologia Veterinária: a Arte do Diagnóstico. São Paulo: Roca, pp.506-526.

5 Cardoso J.C. 2015. Perdas econômicas devido a lesões por aplicação medicamentosas e/ou vacinais em carcaças de bovinos abatidos na região nordeste do Rio Grande do Sul. 27f. Porto Alegre, RS. Monografia (Curso de Especialização em Produção, Tecnologia e Higiene de Produtos de Origem Animal) - Universidade Federal do Rio Grande do Sul.

6 Conselho Federal de Medicina Veterinária. 2012. Resolução no 1.000 , de 11 de maio de 2012. Dispõe sobre procedimentos e métodos de eutanásia em animais e dá outras providências. Disponível em: < http://portal.cfmv.gov.br/ lei/index/id/326>. [Accessed online in August 2017].

7 Frandson R.D., Wilke W.L. \& Fails A.D. 2009. Anatomy of the muscular system. In: Anatomy and Physiology of Farm Animals. Ames: Wiley-Blackwell, pp.105-130.

8 Gaspar E.B., Minho A.P. \& Santos L.R. 2015. Manual de Boas Práticas de Vacinação e Imunização de Bovinos. Bagé: Embrapa Pecuária Sul. [Circular técnica, 47]. 10p.

9 König H.E. \& Liebich H.G. 2007. Axial skeleton. In: König H.E. \& Liebich H.G. (Eds). Veterinary Anatomy of Domestic Mammals. 3rd edn. Stuttgart: Schattauer, pp.49-112.

10 Leal P.V., Pupin R.C., Santos A.C., Faccin T.C., Surdi E., Leal C.R.B., Brumatti R.C. \& Lemos R.A.A. 2014. Estimativas de perdas econômicas causadas por reação granulomatosa local após uso de vacina oleosa contra febre aftosa em bovinos de Mato Grosso do Sul. Pesquisa Veterinária Brasileira. 34(8): 738-742. 
11 Marques A.L.A, Simões S.V.D, Maia L.A., Silva T.R., Miranda Neto E.G., Pimentel L.A., Afonso J.A.B. \& Dantas A.C. 2012. Compressão medular em bovinos associada à vacinação contra febre aftosa. Ciência Rural. 42(10): 18511854.

12 Ministério da Agricultura e Reforma Agrária. 1992. Portaria da Secretaria de Defesa Agropecuária ${ }^{\circ}$ 182, de 16 de julho de 1992. Diário Oficial da União. Disponível em <http://www.aged.ma.gov.br/files/2014/01/PORTN\%C2\%BA-182_16_07_1992.pdf>. [Accessed online in June 2017].

13 Ministério da Agricultura, Pecuária e Abastecimento (MAPA). 2017. Decreto no 9.013, de 29 de março de 2017. Regulamenta a Lei $n^{\circ} 1.283$, de 18 de dezembro de 1950, e a Lei n ${ }^{\text {0 }} 7.889$, de 23 de novembro de 1989, que dispõem sobre a inspeção industrial e sanitária de produtos de origem animal. Disponível em < http://www.planalto.gov.br/ ccivil_03/_ato2015-2018/2017/decreto/D9013.htm>. [Accessed online in August 2017].

14 Ministério da Agricultura, Pecuária e Abastecimento (MAPA). 2006. Secretaria de Defesa Agropecuária. Departamento de Saúde Animal. Programa Nacional de Controle e Erradicação da Brucelose e da Tuberculose Animal (PNCEBT). Disponível em < https://edisciplinas.usp.br/pluginfile.php/3315534/mod_resource/content/1/MANUAL_PNCEBT.pdf> . [Accessed online in July 2017].

15 O’Toole D., McAllister M.M. \& Griggs K. 1995. Iatrogenic compressive lumbar myelopathy and radiculopathy in adult cattle following injection of an adjuvanted bacterin into loin muscle: histopathology and ultrastructure. Journal of Veterinary Diagnostic Investigation. 7: 237-244.

16 Riet-Correa F., Riet-Correa G. \& Schild A.L. 2002. Importância do exame clínico para o diagnóstico das enfermidades do sistema nervoso em ruminantes e equídeos. Pesquisa Veterinária Brasileira. 22(4): 161-168.

17 Tizard I.R. 2014. Vacinas e sua produção. In: Imunologia Veterinária. Rio de Janeiro: Elsevier, pp.258-271.

18 Ubiali D.G., Cruz R.A.S, Lana M.V.C., Meireles Y.S., Néspoli P.B., Souza M.A., Colodel E.M. \& Pescador C.A. 2011. Spinal cord compression in cattle after the use of an oily vaccine. Pesquisa Veterinária Brasileira. 31(11): 997999.

19 United States Department of Agriculture. 2016. Brazil livestock and products annual. Annual livestock 2016. Disponível em <https://s3-sa-east-1.amazonaws.com/usdabrazil.org.br/filer_public/71/9d/719de8f4-941f-49ad-ac5504ac51197a2f/odl8hr.pdf>. [Accessed online in September 2017]. 